NBER WORKING PAPER SERIES

\title{
THE CASE FOR OPEN-MARKET PURCHASES \\ IN A LIQUIDITY TRAP
}

\author{
Alan J. Auerbach \\ Maurice Obstfeld \\ Working Paper 9814 \\ http://www.nber.org/papers/w9814
NATIONAL BUREAU OF ECONOMIC RESEARCH
1050 Massachusetts Avenue
Cambridge, MA 02138
July 2003

We thank Chad Jones, Ronald McKinnon, Christina Romer, and participants in the SIEPR-FRBSF conference on "Finance and Macroeconomics," particularly our discussant Lars Svensson, for helpful discussions and comments on an earlier draft. The paper also benefited from presentation in seminars at USC, UCLA, UC San Diego, Yale, and Chicago GSB. Julian di Giovanni provided expert research assistance. All errors are ours. The views expressed herein are those of the authors and not necessarily those of the National Bureau of Economic Research

(C)2003 by Alan J. Auerbach and Maurice Obstfeld. All rights reserved. Short sections of text not to exceed two paragraphs, may be quoted without explicit permission provided that full credit including $($ notice, is given to the source. 
The Case for Open-Market Purchases in a Liquidity Trap

Alan J. Auerbach and Maurice Obstfeld

NBER Working Paper No. 9814

July 2003

JEL No. E43, E52, E63

\section{$\underline{\text { ABSTRACT }}$}

Prevalent thinking about liquidity traps suggests that the perfect substitutability of money and bonds at a zero short-term nominal interest rate renders open-market operations ineffective for achieving macroeconomic stabilization goals. We show that even were this the case, there remains a powerful argument for large-scale open market operations as a fiscal policy tool. As we also demonstrate, however, this same reasoning implies that open-market operations will be beneficial for stabilization as well, even when the economy is expected to remain mired in a liquidity trap for some time. Thus, the microeconomic fiscal benefits of open-market operations in a liquidity trap go hand in hand with standard macroeconomic objectives. Motivated by Japan's recent economic experience, we use a dynamic general-equilibrium model to assess the welfare impact of open-market operations for an economy in Japan's predicament. We argue Japan can achieve a substantial welfare improvement through large open-market purchases of domestic government debt.

\author{
Alan J. Auerbach \\ Department of Economics \\ University of California \\ Berkeley, CA 94720-3880 \\ and NBER \\ auerbach@econ.berkeley.edu
}

\author{
Maurice Obstfeld \\ Department of Economics \\ University of California \\ Berkeley, CA 94720-3880 \\ and NBER \\ obstfeld@econ.berkeley.edu
}




\section{Introduction}

Japan's efforts to stimulate its economy over the past decade have led to apparent macroeconomic policy paralysis, with short-term nominal interest rates at their floor of zero and fiscal expansion immobilized by fears of increasing an already-huge public debt.

Were short nominal interest rates positive, unanticipated open-market purchases of government debt would have the dual benefits of offsetting deflation and reducing the real value of yen-denominated public obligations. Prevalent thinking about liquidity traps, howeverwhether based on the IS-LM model or on more sophisticated dynamic models such as that of Krugman (1998) - suggests that the perfect substitutability of money and bonds at a zero shortterm nominal interest rate renders open-market operations ineffective as a stabilization tool. ${ }^{1}$

Even in this circumstance, there remains a powerful argument for large-scale open market operations as a fiscal policy tool. To the extent that long-term interest rates are positive now or short-term interest rates are expected to be positive at some point in the future, trading money for interest-bearing public debt reduces future debt-service requirements and hence the distortions of the requisite taxes. Thus, particularly for an economy in Japan's weakening fiscal position, large-scale open-market operations are an attractive policy, even if these operations are perceived to be totally ineffective at influencing current prices or output.

Yet, our analysis shows that this same reasoning implies that open-market operations will be beneficial as a stabilization tool as well, even when the economy is expected to remain mired in a liquidity trap for some time. That is, under the same conditions on interest rates that make

\footnotetext{
${ }^{1}$ King (1999), however, speculates on other channels through which monetary policy might affect the economy even when short-term bond rates are zero. The mechanism we emphasize below is distinct from those that King reviews. In addition, our mechanism does not rely on Bernanke's (2000) "arbitrage" argument for monetary policy effectiveness.
} 
open-market operations attractive for fiscal purposes, a monetary expansion will affect prices and, in the absence of fully flexible prices, output as well. Thus, the microeconomic fiscal benefits of open-market operations in a liquidity trap go hand in hand with standard macroeconomic objectives. ${ }^{2}$

Our analysis shows that beneficial macroeconomic policies need not accelerate an economy's escape from a liquidity trap. Indeed, zero nominal interest rates per se need not be a problem for policy. Problems can stem, however, from the shocks that drive nominal interest rates to zero, and it is to those shocks that policymakers may wish to respond.

In this paper we use a dynamic general-equilibrium model to assess the welfare impact of open-market operations for an economy in Japan's predicament. We argue Japan can achieve a substantial welfare improvement through large open-market purchases of debt. The Bank of Japan has indeed been carrying out such operations through its policy of "quantitative easing," a policy it has accelerated recently, but our analysis suggests that Japanese policymakers should not be timid about going much further in this direction. ${ }^{3}$

In a flexible-price model with monopolistic competition and distorting taxes, we show that even though Japan currently has zero short-term interest rates, an open-market purchase can counteract deflationary price tendencies. In this setting with flexible prices, the policy will improve welfare by reducing the real value of public debt and hence the excess burden of future taxes. Two preconditions must hold for these effects to be possible. First, long-term nominal interest rates must be positive at some horizon (a condition that does hold in Japan today).

\footnotetext{
${ }^{2}$ There is now a large modern literature analyzing alternative strategies for achieving monetary stimulus in a liquidity trap. See Svensson (2001) and Eggertsson and Woodford (2003) for discussion and references.

${ }^{3}$ See Shirakawa (2002) for a discussion of quantitative easing in Japan. Bank of Japan operations that purchase private equities, aside from the political problems involved, yield much more uncertain fiscal benefits (corresponding to the riskier return on the equities).
} 
Second, the central bank must be able to carry out credibly permanent increases in the level (not growth rate) of the money supply, increases that can, but need not, be effected immediately. In Krugman's (1998) account, monetary policy is powerless precisely because of an assumption that the central bank cannot commit itself not to reverse one-off increases in the money supply. Future expected money supply levels are constant because the central bank is assumed unwilling to tolerate any permanent rise in the price level. ${ }^{4}$ Within our dynamic model, however, permanent open-market purchases can yield substantial welfare benefits with only mild inflationary consequences, and we argue accordingly that the credibility problem Krugman assumes is implausible as a total brake on policy effectiveness.

We also analyze a model with staggered nominal price setting in which anticipated deflation has negative welfare effects. In this setting too, an unanticipated open-market purchase is expansionary. While the open-market purchase again has the advantage of devaluing government debt, it has an additional positive welfare effect by causing a Keynesian temporary output increase. There are further welfare impacts, moreover, due to the effects of unexpected and expected inflation on relative price dispersion, but these are unlikely to offset the primary gains.

The final goal of the paper is to simulate numerically the benefits of open-market expansion. We find that, for an economy with Japan's tax rates and public debt to GDP ratio, open-market purchases of government debt yield large welfare benefits. Sizable benefits can be reaped, as we have noted, even when the accompanying inflationary impact is small.

\footnotetext{
${ }^{4}$ Eggertsson and Woodford (2003) restate this result in a more detailed dynamic model.
} 


\section{The Term Structure of Interest Rates in Japan}

A key assumption in the model we develop below is that short-term nominal interest rates, despite being zero today, are expected to be positive at some date (and in some state of nature) in the future. In other words, market participants see at least some chance that the economy will eventually escape from the liquidity trap. This assumption does not seem overly strong; on the contrary, the assumption of a fully permanent liquidity trap is, on its face, quite implausible. We nonetheless offer a more formal argument, based on the current term structure of interest rates in Japan, to show that our assumption about nominal interest-rate expectations is satisfied for that economy.

Figure 1 shows the evolution of Japan's term structure of interest rates since 1997. Shortterm nominal rates are effectively at zero (very slightly positive, but just by enough to cover transaction costs). On the other hand, further out in the term structure-at maturities greater than a year-yields to maturity are higher, with that on the 20-year government bond still around 1 percent per annum.

A simple expectations theory of the term structure would, of course, imply some market expectation of positive future short-term interest rates: otherwise, the entire term structure would be flat at zero rather than upwardly sloped. The expectations theory, however, is highly questionable both on theoretical and empirical grounds. Fortunately we do not need to rely on it. There are other reasons for concluding that the term structure in Figure 1 is inconsistent with the hypothesis of a permanent (with probability 1) liquidity trap. None of the standard explanations for an upward-sloping term structure is plausible in the absence of positive expected future shortterm nominal interest rates. 
Consider first the possibility of conventional risk premia due to investor risk aversion. A major source of uncertainty in bonds' returns, however, is the future behavior of short-term interest rates. If those rates are at zero, they cannot fall. If investors simultaneously cannot envision an eventuality in which short-term rates might rise, then investors no longer consider short-term rates to be random at all. Under that circumstance, it would be impossible to generate risk premia that might justify the term differentials shown in Figure 1. The relative price of present and all future money payments is fixed at unity, so that money is a perfect substitute for bonds of any maturity. 5

Since the yields in Figure 1 are government bond yields, what about the possibility of government default as an explanation for relatively high long-term interest rates? That possibility might seem especially compelling in view of Japan's current high debt-GDP ratio, the likely fiscal costs of financial-sector restructuring, and the alarming forecasts for budgetary developments down the road as the population ages. ${ }^{6}$ A moment's reflection shows that this is not a plausible explanation for positive long-term rates in a world where short-term rates will never rise above zero. The reason is that, in the latter world, the government can trivially finance all its obligations by printing money. Money creation of such a magnitude could eventually ignite inflation, of course; but in that case, the hypothesis of short-term nominal interest rates frozen at zero would be contradicted.

Consider, finally, liquidity effects. With short-term nominal interest rates pegged at zero, marketable debt instruments of different maturities all become equivalent to money, as we have

\footnotetext{
${ }^{5}$ Keynes argued that risk premia would keep long-term rates positive even when short-term rates were zero because at low interest rates, bond-prices are volatile and hence bonds must yield a higher excess return in equilibrium (King 1999, p. 39). Keynes's argument presupposes that markets expect a possible future exit from the liquidity trap.

${ }^{6}$ See, for example, Kashyap (2002) and Dekle (2002).
} 
noted. So again, one cannot rationalize term premia of the sort shown in Figure 1 purely as a liquidity effect.

We conclude that the only plausible explanation for the term structure shown in Figure 1 is that investors attach some positive probability to Japan's some day having positive nominal short-term interest rates. That circumstance, as we now show, is enough to give monetary policy considerable power to enhance economic welfare.

\section{Setup of the Model}

We consider a model in which the representative household maximizes lifetime utility of consumption $\left(C_{t}\right)$ and labor $\left(L_{t}\right)$ over dates $t$ starting at $t=0$,

$U_{0}=\sum_{t=0}^{\infty}\left(\prod_{s=0}^{t} \beta_{s}\right) U\left(C_{t}, L_{t}\right)=\beta_{0} U\left(C_{0}, L_{0}\right)+\beta_{0} \beta_{1} U\left(C_{1}, L_{1}\right)+\beta_{0} \beta_{1} \cdots \beta_{t} U\left(C_{t}, L_{t}\right)$,

where $\beta_{s}$ is the pure discount factor between the end of period $s-1$ and the end of period $s$. (We assume throughout that $\beta<1$ in the long run, so that the product $\prod_{s=0}^{t} \beta_{s}$ converges to 0 as $t \rightarrow$

$\infty$.) We use the dating conventions that consumption and labor occur at the end of the period, assets are indexed by their values at the beginning of the period, and prices are indexed by the end of the period. Throughout most of the analysis, and where not otherwise specified, we use a simplified version of the utility function,

$U\left(C_{t}, L_{t}\right)=\log \left(C_{t}\right)-k_{t} L_{t}$.

Formally, the parameter $k$ represents the disutility of labor, so that changes in $k$ from one period to the next are taste shocks. However, as we will model production as a function of labor alone, 
variations in $k$ will have the same impact as productivity shocks, altering the social cost of transforming forgone leisure into consumption.

There is no capital in the model, so the household holds its financial wealth exclusively in the form of money and interest-bearing government bonds. The household's real wealth at the beginning of period $t$ (before payment of interest) is the sum of its holdings of debt $(B)$ and money $(M)$, divided by the contemporaneous price level $(P)$ :

$V_{t}=\frac{B_{t}+M_{t}}{P_{t-1}}$

Wealth at the beginning of period $t+1$ is

$$
V_{t+1}=\frac{B_{t}\left(1+i_{t}\right)}{P_{t}}+\frac{M_{t}}{P_{t}}+\frac{\pi_{t}}{P_{t}}+\frac{w_{t} L_{t}}{P_{t}}-T_{t}-C_{t}
$$

where $i_{t}$ is the nominal interest rate between periods $t-1$ and $t$, and $w_{t}, \pi_{t}, T_{t}$, and $C_{t}$ are, respectively, the nominal and wage rate, nominal profits, real taxes and real consumption in period $t$. Combining these two equations and defining the real interest rate by $r_{t} \equiv\left(1+i_{t}\right) /\left(P_{t} / P_{t-1}\right)-1$ yields an expression for the evolution of household wealth:

$V_{t+1}=V_{t}\left(1+r_{t}\right)-\frac{i_{t} M_{t}}{P_{t}}+\frac{\pi_{t}}{P_{t}}+\frac{w_{t} L_{t}}{P_{t}}-T_{t}-C_{t}$

To model money demand, we assume that households face a cash-in-advance constraint, needing to hold money in period $t$ that is sufficient to purchase goods at the end of period $t$. Taxes are collected in the form of consumption taxes, and households are also required to hold 
cash in order to pay the taxes on their consumption purchases. If $\tau_{t}$ is the consumption tax rate at date $t$, the cash-in-advance constraint,

$M_{t} \geq\left(1+\tau_{t}\right) P_{t} C_{t}$,

is binding unless the nominal interest rate is zero, so that it is always the case that $i_{t} M_{t}=i_{t}\left(1+\tau_{t}\right) P_{t} C_{t}$. Using this fact, we can rewrite the evolution of wealth as

$V_{t+1}=V_{t}\left(1+r_{t}\right)+\frac{\pi_{t}}{P_{t}}+\frac{w_{t} L_{t}}{P_{t}}-T_{t}-\left(1+i_{t}+\tau_{t} i_{t}\right) C_{t}$

Because tax collections are given by $T_{t}=\tau_{t} C_{t}$, household wealth evolves as

$V_{t+1}=V_{t}\left(1+r_{t}\right)+\frac{\pi_{t}}{P_{t}}+\frac{w_{t} L_{t}}{P_{t}}-\left(1+\tau_{t}\right)\left(1+i_{t}\right) C_{t}$

Solved forward with the transversality condition imposed, this difference equation yields the lifetime budget constraint of the household:

$V_{0} \geq \sum_{t=0}^{\infty}\left(\prod_{s=0}^{t}\left(1+r_{s}\right)^{-1}\right)\left[\left(1+\tau_{t}\right)\left(1+i_{t}\right) C_{t}-\frac{\pi_{t}}{P_{t}}-\frac{w_{t} L_{t}}{P_{t}}\right]$

Maximizing utility subject to this budget constraint results in first-order conditions for consumption and labor at each date. Combining the conditions for consumption and labor at date $t$ yields a solution for household consumption at date $t$,

$C_{t}=\frac{w_{t}}{k_{t}\left(1+i_{t}\right)\left(1+\tau_{t}\right) P_{t}}$, 
in which an increase in the labor-disutility parameter, $k$, has the same impact as a decline in the real wage, discouraging work, consumption, and hence output.

Combining conditions for consumption at successive dates $t$ and $t+1$ yield the Euler equation,

$$
\frac{C_{t+1}}{C_{t}}=\beta_{t+1}\left(1+i_{t+1}\right) \frac{P_{t}\left(1+\tau_{t}\right)\left(1+i_{t}\right)}{P_{t+1}\left(1+\tau_{t+1}\right)\left(1+i_{t+1}\right)}=\beta_{t+1}\left(1+i_{t}\right) \frac{P_{t}\left(1+\tau_{t}\right)}{P_{t+1}\left(1+\tau_{t+1}\right)}
$$

Note that the cash-in-advance constraint has the effect of replacing the interest rate between dates $t$ and $t+1$ with the preceding period's interest rate.

We assume that consumption at each date is a composite good. A continuum of producers supplies the individual consumption goods under conditions of market power. We model nominal price stickiness by postulating that each producer must set a nominal price that is maintained over two periods. That is, a posted price is good for the period in which it is set and the following period, with all market demand supplied at that price (as long as price exceeds marginal cost). Price setting is staggered across the two classes of goods. Half of the goods, class 1 , have their prices set in odd-numbered periods, while the other half, class 2 , have their prices set in even periods. Goods within each type enter the utility function symmetrically, and all goods are produced subject to the simple production function $Y=L$. Letting $c_{t i}(z)$ be the type- $z$ good in class $i$ at date $t$, the relationship between the composite consumption good and underlying individual commodity consumption is:

$$
C_{t}=2 C_{t 1}^{1 / 2} C_{t 2}^{1 / 2} \quad \text { where } \quad C_{t i}=\left[\int_{0}^{1} c_{t i}(z)^{\frac{\rho-1}{\rho}} d z\right]^{\frac{\rho}{\rho-1}}, \rho>1, i=1,2 .
$$


That is, goods enter utility via a Cobb-Douglas function of the two class composites, each of which is a CES function of individual types of consumption. The corresponding producer price index is

$$
P_{t}=P_{t 1}^{1 / 2} P_{t 2}^{1 / 2} \quad \text { where } \quad P_{t i}=\left[\int_{0}^{1} p_{t i}(z)^{1-\rho} d z\right]^{\frac{1}{1-\rho}} .
$$

\section{Effects of Monetary Policy when Short-Term Nominal Interest Rates are Zero: The Flexible-Price Case}

It is clearest to start by analyzing open-market operations under the temporary assumption that nominal goods prices are perfectly flexible, that is, are set for one period only. In that case, even though there are two sectors of the economy, monetary shocks have symmetric effects on the sectors' outputs, employments, and prices, and do not drive relative intersectoral prices away from unity.

Initially the cash-in-advance constraint (2) does not bind and the nominal interest rate $i=$ 0 , which can occur because expected money growth rates are low (and perhaps even negative) relative to the subjective discount rates reflected in the preference parameters $\beta_{s}$. As per our discussion above, however, we assume that some long-term interest rate is positive (as is currently true in Japan), so that on at least one date $T$ in the future, $i_{T}>0$. (Perhaps on that date, consumers become more impatient or the rate of money-supply growth rises.) We show that under flexible prices, monetary policy can affect the price level before date $T$, notwithstanding the economy's zero nominal interest rate. That is, any prospect of future nominal interest rates above zero, no matter how remote, implies that the economy cannot be in a monetary-policy trap 
beforehand. Indeed it suffices, once can show, that there be some future state of nature, occurring with any positive probability, in which $i_{T}>0$.

Start with the Euler equation (4) for date $t$, expressed in terms of nominal wages rather than prices based on the conditions (3) for the consumption-labor decisions at dates $t$ and $t+1$. The result has the very simple form of an "inverse wage Euler equation,"

$$
\frac{w_{t+1}}{k_{t+1}}=\left(1+i_{t+1}\right) \beta_{t+1} \frac{w_{t}}{k_{t}}
$$

We have assumed, however, that the economy is in a liquidity trap and the interest rate is zero from the present date, 0 , through period $T-1$. At date $T$, the interest rate is positive and the cash-in-advance constraint is binding. To be concrete we will also assume that short-term the nominal interest rate also remains positive for all dates after $T$, but only some inessential details of our argument change if that is not the case. Under these assumptions, from (5), the wage rate for each date $t<T-1$ obeys the expression

$\frac{w_{t}}{k_{t}}=\frac{1}{\beta_{t+1}} \frac{w_{t+1}}{k_{t+1}}$

From (6), we observe that the wages (and prices) rise, fall or remain constant during the zerointerest regime according to whether the term $\beta_{t+1} \frac{k_{t+1}}{k_{t}}$ is greater than, less than or equal to 1 .

For each period $t>T-1$, we have, from the original Euler equation (4) and the cash-inadvance constraint, (2),

$$
\frac{M_{t+1}}{M_{t}}=\beta_{t+1}\left(1+i_{t}\right) \Rightarrow\left(1+i_{t}\right)=\frac{M_{t+1}}{M_{t} \beta_{t+1}}
$$


From (5) and (6), the wage evolves from date $T$ onward according to

$$
\frac{w_{t}}{k_{t}}=\frac{\beta_{t}}{\beta_{t+1}} \frac{M_{t+1}}{M_{t}} \frac{w_{t-1}}{k_{t-1}}
$$

Thus, once we have an expression for $w_{T-1},(7)$ and (8) provide us with the entire path of wage rates both before date $T-1$ and after $T-1$.

To solve for $w_{T-1}$, write the Euler equation (3) for dates $T-1$ and $T$, substituting the cashin-advance constraint (2) at $T$ and the labor-consumption condition (3) at $T-1$, to obtain $\frac{M_{T}}{w_{T-1} / k_{T-1}}=\beta_{T}$, and so, $\frac{w_{T-1}}{k_{T-1}}=\frac{M_{T}}{\beta_{T}}$. As a result, the general solution for the path of wages is:

$\frac{w_{t}}{k_{t}}=\left(\prod_{s=t+1}^{T-1} \beta_{s}^{-1}\right) \frac{M_{T}}{\beta_{T}}, \quad t \leq T-1$

$$
\frac{w_{t}}{k_{t}}=\frac{M_{t+1}}{\beta_{t+1}}, \quad t \geq T-1
$$

(Note that these two expressions are the same for $t=T-1$.)

We can now see how a permanent step increase $\Delta M_{0}$ in the money supply's level on date 0 will affect the economy. Let's assume that the increase in the money supply on date 0 does not change any future monetary growth rates $M_{t+1} / M_{t}, t \geq 0$. In that case, $M_{T}$ rises by the factor $1+$ $\Delta M_{0} / M_{0}$ (as do all subsequent money-supply levels). ${ }^{7}$

\footnotetext{
${ }^{7}$ As will be discussed below, the date upon which the nominal interest rate becomes positive does not change as a result of this policy.
} 
Equation (9) shows that, notwithstanding zero nominal interest rates prior to date $T$, all future nominal wage rates, including those for dates 0 through $T-1$, will be scaled by the factor $1+\Delta M_{0} / M_{0}$. As can be shown from the more general analysis of price-setting behavior given below, with perfectly flexible product prices, monopolists charge a fixed percentage markup over the wage, so that $P_{t}=\rho w_{t} /(\rho-1)$. Therefore, the current and all future price levels rise by the same percentage as do wages. During a period of zero short-term nominal interest rates, the price level's path is governed by the money stock expected for the first date on which interest rates turn positive.

The intuition is disarmingly simple. On the first day the short-term interest rate turns positive, the money stock determines the price level in the conventional way. As long as the interest rate is zero, however, prices move toward that conventionally determined value at a rate governed by consumers' rate of time preference. By raising the money stock's level permanently today, the monetary authority can shift upward the date $T$ terminal condition on the price level. That action necessarily also shifts upward the entire time profile of prices prior to date $T$.

The irrelevance of the current money supply to the economy's equilibrium, given money supplies on future positive-interest-rate dates, is the essence of the liquidity trap. However, the central bank can affect today's equilibrium by changing expectations of future money supplies. In our analysis, the central bank changes those expectations simply by changing the money stock's level immediately and allowing "base drift."

Our infinite-horizon model is in essence just a dynamic extension of Krugman's (1998). Krugman, however, assumes a liquidity trap in the initial period of his model, with an exit form the liquidity trap in the second period and all relevant economic variables stationary thereafter. 
In our model, however, the liquidity trap can be long-lasting, even indefinitely so in some states of the world. If markets expect the possibility of positive interest rates at any point in the future, however, an immediate action - increasing the date 0 money supply while making no corresponding reduction in future money supply levels—will immediately lift prices.

Of course, one reason that markets might expect positive short-term interest rates in the future would be a government commitment to higher monetary growth rates then. Krugman (1998) and others have argued that such a commitment might be problematic. There are other mechanisms, however, that could produce zero interest rates now, coupled with expectations of future positive interest rates: predictable shifts in productivity growth, predictable shifts in time preference, or (outside the scope of the present model) demographic changes. To consider two concrete examples that might apply to Japan's current circumstances, an aging baby boom cohort with life-cycle savings behavior could induce a very high short-run saving rate that, in the context of our representative-agent model, would translate into a very low discount rate and a very high value for the discount factor, $\beta$. This would be particularly true if government promises of old-age pensions were viewed with some skepticism. A similar effect would occur if substantial pessimism or higher risk perceptions induced a rise in precautionary saving.

In general, it is difficult to believe that economic actors would not attach some positive probability to the event of positive interest rates on some, perhaps distant, future date. Nor is it plausible (as we ague in greater detail below) that they would necessarily expect any monetary expansion to be reversed with probability 1 . These conditions would be enough to render current monetary expansion effective, as a stochastic extension of our model shows.

It is worth noting that, although we have modeled a closed economy, extension to the open case is easy. Under a zero domestic nominal interest rate, and with a positive nominal 
interest rate abroad, the currency would appreciate over time so as to preserve uncovered interest parity. Since that appreciation would exactly offset the difference between domestic and foreign price inflation, relative international prices would not change. ${ }^{8}$

\section{Welfare Analysis of an Open-Market Purchase of Government Bonds under Flexible Prices}

Consider the impact on welfare of an open-market operation, as measured by a policy index $\xi$.

Given the expression for household utility, we have the general expression

$$
\frac{d U_{0}}{d \xi}=\sum_{t=0}^{\infty}\left(\prod_{s=0}^{t} \beta_{s}\right)\left(1-k_{t} C_{t}\right) \frac{1}{C_{t}} \frac{d C_{t}}{d \xi}=\sum_{t=0}^{\infty}\left(\prod_{s=0}^{t} \beta_{s}\right)\left(1-\frac{1}{\left(1+i_{t}\right)\left(1+\tau_{t}\right)\left(P_{t} / w_{t}\right)}\right) \frac{1}{C_{t}} \frac{d C_{t}}{d \xi}
$$

which makes use of the fact that, with flexible prices, the aggregate consumption index $C_{t}$ equals the aggregate labor input, $L_{t}{ }^{9}$ Note that this derivative will vanish if there is no seigniorage $(i=0)$, no taxes $(\tau=0)$, and no producer mark-ups $(P / w=1)$ : with no distortions present, the allocation is Pareto optimal and any perturbation has no first-order welfare impact. More generally, all of these distortions will be positive and hence cumulative, and any policy that increases consumption will increase welfare.

Let us assume for simplicity that the tax rate $\tau$ is always set so as to be constant over time. If we continue to assume that the experiment $\xi$ holds $M_{t+1} / M_{t}$ fixed in the future, then all of the effects on utility will occur through the tax rate $\tau$. Using expression (3), we obtain ${ }^{10}$ :

\footnotetext{
${ }^{8}$ The Japanese yen's longstanding secular appreciation process seems to have stopped despite the zero short-term interest rate and the consequent apparent excess return on non-yen currencies. This pattern is difficult to rationalize in a nonstochastic model. Goyal and McKinnon (2003) argue that Japanese investors attach a substantial risk premium to dollar assets, and that this explains the current international configuration of exchange rates and nominal interest rates.

${ }^{9}$ When producer prices are equal for all goods $z$ in sector $i(=1,2)$, as is true throughout our analysis, the labor input for sector $i$ equals that sector's sub-index, e.g., $L_{t i}=C_{t i}$. Thus, aggregate labor input $L_{t}=L_{t 1}+L_{t 2}=C_{t 1}+C_{t 2}$, while the aggregate consumption index is $C_{t}=2\left(C_{t 1} C_{t 2}\right)^{1 / 2}$. With flexible prices, $C_{t 1}=C_{t 2}$ and hence $C_{t}=L_{t}$.
} 


$$
\frac{d U_{0}}{d \xi}=(1+\tau) \frac{d\left(\frac{1}{1+\tau}\right)}{d \xi} \sum_{t=0}^{\infty}\left(\prod_{s=0}^{t} \beta_{s}\right)\left(1-\frac{(\rho-1)}{\rho\left(1+i_{t}\right)(1+\tau)}\right)=-\frac{d \ln (1+\tau)}{d \xi} \sum_{t=0}^{\infty}\left(\prod_{s=0}^{t} \beta_{s}\right)\left(1-\frac{\rho-1}{\rho\left(1+i_{t}\right)(1+\tau)}\right)
$$

We can also express the change in utility in dollars (or yen). Starting again with condition (10), use the first-order condition for consumption at each date $t$,

$$
\left(\prod_{s=0}^{t} \beta_{s}\right) \frac{1}{C_{t}}=\lambda\left(\prod_{s=0}^{t}\left(1+r_{s}\right)^{-1}\right)\left(1+\tau_{t}\right)\left(1+i_{t}\right)
$$

(where $\lambda$ is the multiplier on the household lifetime budget constraint) to substitute and get

$$
\begin{aligned}
& \frac{d U_{0}}{d \xi}=\lambda \sum_{t=0}^{\infty}\left(\prod_{s=0}^{t}\left(1+r_{s}\right)^{-1}\right)\left(\left(1+\tau_{t}\right)\left(1+i_{t}\right)-\frac{1}{\left(P_{t} / w_{t}\right)}\right) \frac{d C_{t}}{d \xi} \\
& =\frac{\lambda}{P_{-1}} \sum_{t=0}^{\infty}\left(\prod_{s=0}^{t}\left(1+i_{s}\right)^{-1}\right)\left(\left(1+\tau_{t}\right)\left(1+i_{t}\right) P_{t}-w_{t}\right) \frac{d C_{t}}{d \xi} .
\end{aligned}
$$

Because $\lambda$ is the marginal utility of real wealth at date $0, \lambda / P_{-1}$ is the marginal utility of nominal wealth at date 0 (remember that real wealth at date 0 is obtained by deflating nominal wealth by $\left.P_{-1}\right)$. Thus we can divide both sides by $\lambda / P_{-1}$ to get the dollar value, at date 0 , of the open market operation, say $\Delta$,

$$
\Delta=\sum_{t=0}^{\infty}\left(\prod_{s=0}^{t}\left(1+i_{s}\right)^{-1}\right)\left(\left(1+\tau_{t}\right)\left(1+i_{t}\right) P_{t}-w_{t}\right) \frac{d C_{t}}{d \xi}
$$

\footnotetext{
${ }^{10}$ This expression can be simplified further if we assume that the discount factor is constant at some value, say $\beta_{0}$, through period $T$, and constant at some different value, $\beta_{1}$, from period $T+1$ onward, and the net money growth rate is constant from $T$ onward at some rate $\mu-1$. For $\beta_{0}<1$ (a comparable expression applies for $\beta_{0}>1$ ), the simplified expression is:$$
\frac{d U_{0}}{d \xi}=-\frac{d \ln (1+\tau)}{d \xi}\left\{\left(\frac{\beta_{0}-\beta_{0}^{T+1}}{1-\beta_{0}}\right)\left(1-\frac{\rho-1}{\rho(1+\tau)}\right)+\left(\frac{\beta_{0}^{T+1}}{1-\beta_{1}}\right)\left(1-\frac{(\rho-1) \beta_{1}}{\rho \mu(1+\tau)}\right)\right\} .
$$ 
which is a standard result that marginal deadweight loss equals the product of the wedge (due to taxes, seigniorage and noncompetitive producer mark ups) times the changes in the distorted quantity (i.e., in vector notation, $\mathbf{t}^{\prime} \Delta \mathbf{X}$ ).

For the case we have considered thus far, of flexible prices, $M_{t+1} / M_{t}$ fixed in the future, and a constant tax rate $\tau$, we have $\frac{d C_{t}}{d \xi}=-C_{t} \frac{d \ln (1+\tau)}{d \xi}$, so

$$
\Delta=-\frac{d \ln (1+\tau)}{d \xi} \sum_{t=0}^{\infty}\left(\prod_{s=0}^{t}\left(1+i_{s}\right)^{-1}\right)\left((1+\tau)\left(1+i_{t}\right) P_{t}-w_{t}\right) C_{t} .
$$

The summation in (12) equals the present value of revenue, from taxes and seigniorage, plus monopoly profits, so the dollar value of the welfare effect equals that total times minus the percentage change in $(1+\tau)$. This expression can be further evaluated using the expression for $\tau$ derived in Equation (A1) in the Appendix. ${ }^{11}$

Expressions (11) and (12) provide a convenient framework for considering the impact of alternative preference assumptions on the magnitude of estimated welfare gains. One can generalize the preferences assumed thus far, based on expression (1) for within-period utility, to

$$
U\left(C_{t}, L_{t}\right)=\left(1-\frac{1}{\gamma}\right)^{-1} C_{t}^{1-\frac{1}{\gamma}}-k_{t} L_{t}
$$

${ }^{11}$ For the special case considered in footnote 10, the expression for $\tau$ simplifies to:

$$
\tau=\frac{\left(\frac{M_{0}+B_{0}}{M_{T}}\right) \beta_{0}^{T+1}-\left(1-\frac{\beta_{1}}{\mu}\right) \frac{\beta_{0}^{T+1}}{1-\beta_{1}}}{\left(1-\beta_{0}^{T+1}\right) \frac{\beta_{0}}{1-\beta_{0}}+\beta_{0}^{T+1} \frac{\beta_{1}}{1-\beta_{1}}-\left(\frac{M_{0}+B_{0}}{M_{T}}\right) \beta_{0}^{T+1}} .
$$


in which the parameter $\gamma$, equal to the intertemporal elasticity of substitution of consumption, may take on values other than 1 (the logarithmic case). For this more general specification of utility, the analysis thus far goes through with minor modifications, notably that the relationship between consumption and labor at date $t$ now follows the more general rule

$C_{t}=\left(\frac{w_{t}}{k_{t}\left(1+i_{t}\right)\left(1+\tau_{t}\right) P_{t}}\right)^{\gamma}$

Expression (11) is not affected by this change in assumption, but using ( $\left.3^{\prime}\right)$ rather than (3) to simplify leads to a modified version of expression (12),

$$
\Delta=-\gamma \frac{d \ln (1+\tau)}{d \xi} \sum_{t=0}^{\infty}\left(\prod_{s=0}^{t}\left(1+i_{s}\right)^{-1}\right)\left((1+\tau)\left(1+i_{t}\right) P_{t}-w_{t}\right) C_{t} .
$$

We see from (12') that the welfare change is scaled by the intertemporal consumption elasticity, so that, as one would expect, less sensitive preferences would lead to lower estimates of the welfare change. ${ }^{12}$ This result should be kept in mind below as we discuss the magnitude of potential welfare gains from policy changes.

\section{The Sticky-Price Case}

Continuing to assume that wages are flexible, let us drop the temporary assumption that prices are flexible and consider staggered two-period setting of nominal product prices. From the assumption of profit maximization by producers and the household's Euler equation, we obtain the following expression for the price index for class- $i$ goods, whose price is reset in period $t$ :

\footnotetext{
${ }^{12}$ A full analysis of the impact of changes in $\gamma$ would also need to account for differences in the induced change in $\tau$.
} 
$P_{t i}=\frac{\rho}{\rho-1}\left[\frac{w_{t}+\beta_{t+1} w_{t+1} a_{t} / a_{t+1}}{1+\beta_{t+1} a_{t} / a_{t+1}}\right], \quad$ where $a_{t}=\left(1+\tau_{t}\right)\left(1+i_{t}\right)$

Thus, the overall price level in period $t$ is:

$P_{t}=\frac{\rho}{\rho-1}\left[\frac{w_{t}+\beta_{t+1} w_{t+1} a_{t} / a_{t+1}}{1+\beta_{t+1} a_{t} / a_{t+1}}\right]^{1 / 2}\left[\frac{w_{t-1}+\beta_{t} w_{t} a_{t-1} / a_{t}}{1+\beta_{t} a_{t-1} / a_{t}}\right]^{1 / 2}$.

Note that this price level expression holds when wages, taxes and interest rates equal the values assumed by producers when prices are set. If we consider an unanticipated policy change at date $t$, then the prices set in period $t-1$ will not obey the above expression for $P_{t i}$, ex post.

If the interest rate, tax rate, wage inflation rate, and discount factor are all constant over time, then the expression for $P_{t}$ simplifies to

$P_{t}=w_{t} \frac{\rho}{(\rho-1)(1+\beta)}(1+\beta \mu)^{1 / 2}\left(\mu^{-1}+\beta\right)^{1 / 2}$,

where $\mu$ is 1 plus the inflation rate. From this expression, it can be shown that the mark-up, $P_{t} / w_{t}$, is a decreasing function of $\mu$ for $\mu \beta<1$ and an increasing function for $\mu \beta>1$; that is, the mark-up is decreasing with inflation until the rate of inflation equals the pure rate of time preference. Since welfare is inversely related to the markup, this is therefore a model in which even anticipated deflation has welfare costs, and anticipated inflation has some beneficial 
welfare effects for sufficiently small inflation rates, consistent with the conjecture of Akerlof, Dickens, and Perry (1996). ${ }^{13}$

A major difference now is that it is no longer true that $L=C$. In essence, relative-price distortion between the two price-staggering sectors will lower the consumption index $C$ below the cost of production $L=C_{1}+C_{2}$ whenever the prices charged by the sectors are not equal. So we must calculate aggregate labor supply as the sum of supplies to the two sectors of the economy, which still equal their respective consumption sub-aggregates.

Our goal is to evaluate how lifetime utility

$U_{0}=\sum_{t=0}^{\infty}\left(\prod_{s=0}^{t} \beta_{s}\right)\left[\log \left(C_{t}\right)-k_{t}\left(C_{t 1}+C_{t 2}\right)\right]$

is affected by an open market purchase of government bonds. As noted above, in the disutility of labor term we can no longer assert that $L=C$ because, with sticky prices, there will generally be asymmetric labor supply to the two sectors of the economy. Since, however,

$$
C_{t i}=\frac{1}{2}\left(\frac{P_{t i}}{P_{t}}\right)^{-1} C_{t}
$$

we can write utility as

$$
U_{0}=\sum_{t=0}^{\infty}\left(\prod_{s=0}^{t} \beta_{s}\right)\left[\log \left(C_{t}\right)-k_{t}\left(\frac{P_{t 1}+P_{t 2}}{2 P_{t 1}^{1 / 2} P_{t 2}^{1 / 2}}\right) C_{t}\right] .
$$

\footnotetext{
${ }^{13}$ See Wolman (2001) for another model with this property, and Woodford (2003) for a general treatment of inflation and welfare. Schmitt-Grohé and Uribe (2002) analyze optimal monetary and fiscal policy in an economy with nominal price rigidities.
} 
Note that the ratio of arithmetic to geometric means is always greater than 1 unless the two prices are equal. Thus, the second term in the period utility function incorporates the effects of relative price distortions. Alternatively, let $\delta_{t}=P_{t 1} / P_{t 2}$ measure the relative price distortion on date $t$. Then utility has the form $U_{0}=\sum_{t=0}^{\infty}\left(\prod_{s=0}^{t} \beta_{s}\right)\left[\log \left(C_{t}\right)-k_{t}\left(\frac{1+\delta_{t}}{2 \delta_{t}^{1 / 2}}\right) C_{t}\right]$

Define the relative-price distortion term as $\phi(\delta) \equiv(1+\delta) / 2 \delta^{1 / 2}$. Notice that the derivative $\phi(\delta)=$ $\left(\delta^{1 / 2}-\delta^{-1 / 2}\right) / 4 \delta$, which is negative for $\delta<1$, and that $\phi(\delta)=\phi(1 / \delta)$.

For simplicity assume that $\beta$ is a constant. If we are initially in a position where pricesetters' expectations have been realized and the nominal interest rate is 0 , then one can show that even with sticky prices $\delta=\beta$ will hold. That is, relative prices (like the price level) are falling at the rate of time preference. In that setting, a small enough unexpected monetary expansion will raise the prices that are currently set and (for one period) push $\delta$ closer to 1, raising welfare through that channel. But a large enough monetary expansion will temporarily exacerbate the relative-price distortion. This gives a rigorous account of the specific costs of unanticipated inflation (as opposed to the better-known costs of anticipated inflation in the optimum quantity of money discussion). ${ }^{14}$ Of course, we will have a second unanticipated inflation effect on welfare through the output channel along with a second anticipated inflation effect on the average markup.

These effects are all captured in the expression below:

\footnotetext{
${ }^{14}$ Such effects of unanticipated inflation have been assumed on an ad hoc basis in models such as that of Barro and Gordon (1983) in order to avoid the Calvo (1978) problem of potentially unbounded Nash-equilibrium inflation rates.
} 


$$
\frac{d U_{0}}{d \xi}=\sum_{t=0}^{\infty} \beta^{t+1}\left\{\left[1-k_{t} \phi\left(\delta_{t}\right) C_{t}\right] \frac{1}{C_{t}} \frac{d C_{t}}{d \xi}-k_{t} \phi^{\prime}\left(\delta_{t}\right) C_{t} \frac{d \delta_{t}}{d \xi}\right\}
$$

Alternatively, based on expression (3) for total consumption, which continues to hold even under staggered pricing,

$$
\frac{d U_{0}}{d \xi}=\sum_{t=0}^{\infty} \beta^{t+1}\left\{\left[1-\frac{\phi\left(\delta_{t}\right)}{\left(1+i_{t}\right)\left(1+\tau_{t}\right)\left(P_{t} / w_{t}\right)}\right] \frac{1}{C_{t}} \frac{d C_{t}}{d \xi}-\frac{\phi^{\prime}\left(\delta_{t}\right)}{\left(1+i_{t}\right)\left(1+\tau_{t}\right)\left(P_{t} / w_{t}\right)} \frac{d \delta_{t}}{d \xi}\right\}
$$

Only in the absence of distortions — that is, with $i=\tau=0$ and $P / w=\delta=1$ - is this derivative guaranteed to be zero, of course.

The first component of the preceding expression, involving the derivative of total consumption with respect to the policy action $\xi$, can be calculated just as in the last section. Now, though, the intersectoral relative-price distortion term $\phi(\delta) \geq 1$ reduces the utility value of increments in total consumption. However, with sticky prices the effect of the policy change $d \xi$ on the future path of consumption will differ compared to the flexible-price case. In the present setup, with two-period staggered price-setting, an unexpected monetary expansion on date 0 would raise $C_{0}$ above its flexible-price level. This short-run Keynesian effect, associated with a fall in the markup, would reinforce the positive consumption effect due to lower taxes.

The second term above, that involving the derivatives $\phi^{\prime}(\delta)$, reflects the additional price distortion associated with the policy change. Let us continue to assume that the tax rate is constant and that the open-market purchase at date 0 leaves all future rates of monetary growth unaltered. In that case, only the term $\phi^{\prime}\left(\delta_{0}\right)$ above is nonzero; $\phi^{\prime}\left(\delta_{1}\right)=\phi^{\prime}\left(\delta_{2}\right)=\ldots=0$ because the only unanticipated shock occurs on date 0 , subsequent money-supply growth rates are 
unchanged, and by date 1 (with two-period overlapping contracts), the pre-shock intersectoral price distribution therefore has been restored. ${ }^{15}$

As we have noted, when the nominal interest rate is zero it is initially the case that $\delta=\beta$ (we assume for simplicity that $t<T-2$ ). Because taxes immediately rise to their new constant level as a result of the surprise monetary expansion on date 0 , the new relative price on date 0 is given by

$\delta_{0}=\beta\left(1+\Delta M_{0} / M_{0}\right)$

Thus, the additional marginal welfare effect due to the induced date 0 change in intersectoral price dispersion is

$$
-\frac{\phi^{\prime}(\beta) \beta}{(1+\bar{\tau})(\overline{P / w})} \frac{d\left(\Delta M_{0} / M_{0}\right)}{d \xi}
$$

where overbars indicate pre-shock levels for the tax rate and markup. As noted above, for a small change the preceding welfare effect is positive, because the initial trend deflation at the rate of time preference is reduced for a period.

The preceding utility effects can be translated into dollar terms using the same transformation we employed in Section V.

\section{Quantitative Estimates of Welfare Gains}

How large might the welfare gains from open-market operations be? As just discussed, the effects in the fixed-price case are different only in transitory ways from those of the flexible-

\footnotetext{
${ }^{15}$ As in the flexible-price case, it remains true that an unexpected monetary expansion on date 0 will not, under our assumptions, change the date on which the nominal interest rate first turns positive.
} 
price case, so we can get a rough first estimate of the magnitude by using expression (12), for the welfare effects under flexible prices. That expression says that the welfare effects of an open market operation equal the product of the present value of tax revenues, seigniorage and noncompetitive rents, multiplied by minus the percent change in the term $(1+\tau)$, roughly the absolute reduction in the tax rate itself.

To get some idea of the responsiveness of this term to monetary policy, consider the special case in which the discount factor, $\beta$, is constant in the zero interest rate regime at some value, say $\beta_{0}$, and constant at some possibly different value, say $\beta_{1}<1$, in the subsequent positive interest rate regime. As discussed above, a temporarily low discount rate could be a contributing cause of a liquidity trap. Under this assumption, an increase in the money stock at date $T, M_{T}$, would have the following impact on $(1+\tau)$ :

$-\frac{d \ln (1+\tau)}{d \ln M_{T}}=\frac{1}{X-1}$

where $^{16}$

$$
X=\left[\beta_{0}^{-T}+\beta_{0}^{-(T-1)}+\ldots+\beta_{0}^{-1}+1+\beta_{1}+\beta_{1}^{2}+\ldots\right] \frac{M_{T}}{M_{0}+B_{0}}
$$

Suppose, for example, that the pure rate of time preference currently in year zero is $-0.03\left(\beta_{0}=\right.$ $1 / 0.97)$, and that it is expected to increase to $+0.02\left(\beta_{1}=1 / 1.02\right)$ in year $T=5$. Then the term in brackets in (13) equals $\left(1-(0.97)^{6}\right) / 0.03+1 / 0.02=55.6$. Hence, for $M_{T}=M_{0}$ initially, and a ratio

\footnotetext{
${ }^{16}$ Observe that since $\tau$ is finite, it must be true that $X>1$.
} 
of high-powered money to total government debt (including money) of $0.2,{ }^{17} X=11.1$, and hence $-\frac{d \ln (1+\tau)}{d \ln M_{T}}=(1 / 10.1)$

To obtain a lower-bound estimate of welfare effects, let's ignore seigniorage and noncompetitive rents in expression (12) and consider only the percentage of National Income currently raised through taxes. (We present a more complete numerical analysis in the next section.) Our calculation relates to a hypothetical level tax rate consistent with intertemporal budget balance, whereas Japan's general government deficit now exceeds 8 percent of National Income. So we use as our tax rate the Ministry of Finance (2002, sec. II.8) estimate of the overall "potential national burden," which includes hypothetical tax receipts that would suffice to eliminate the current fiscal deficit. That number was 47 percent of National Income for 2002 (and is surely over-optimistic given future social security obligations and financial-sector restructuring costs). ${ }^{18}$ From expression (12), we therefore infer a permanent annual welfare gain equal to $0.47 / 10.1$, or nearly 0.05 percent of National Income for each percent increase in the money stock at date $T$. This is a huge marginal welfare benefit (and as we have noted, is likely an underestimate of the true benefit that is implied by the model). Extrapolated linearly, it implies that a 100 percent increase in the monetary base would raise welfare permanently by an amount equal to 5 percent of National Income per year, although linearity breaks down for such a large monetary expansion and the true effect would be smaller. Because the model has some

\footnotetext{
${ }^{17}$ Japan's current monetary base is about 18 percent of nominal GDP and the level of net outstanding general government bond debt is roughly 70 percent of GDP (with the more widely cited gross government debt figure about twice as high).

${ }^{18}$ Our model, which abstracts from government spending, implies that $\tau=\left\{1-\left[M_{T} /\left(M_{0}+B_{0}\right)\right]\right\} /(1-X)$ (assuming that $\mu=1)$. While the model is appropriate for capturing quantitatively the seigniorage gains from government bond buybacks and the resultant impact on the "permanent" tax rate, it predicts a tax rate that is much too low and it therefore underestimates the deadweight tax burden. Accordingly we use the actual tax burden to substitute for $\tau$ in expression (12).
} 
specific simplifying assumptions (including logarithmic consumption preferences), this number should be taken to indicate substantial welfare benefits rather than as a literal best estimate.

\section{Simulating Various Policy Changes}

The preceding section's analysis illustrates the potential welfare benefits of open market operations in a liquidity trap, but with some limits. First, it starts from the premise that a liquidity trap exists and will end at a certain future date, and hence is applicable only to policies that do not affect the duration of the liquidity-trap regime. Second, it is accurate only for small open market operations. Third, it does not deal with the effects of sticky prices.

To get a more general idea of the effects of policy changes of different sizes in a variety of environments, including those changes that may affect the dates at which the economy exits the liquidity trap, we turn to numerical simulations. As one cannot determine ex ante whether the economy will be in a liquidity trap in a given period, the key to the methodology is identifying periods in which the economy is constrained. We accomplish this through the following backward solution technique.

Assume first that we know the state of the economy at date $t+1$, including whether the economy is in a liquidity trap (i.e., whether $i_{t+1}=0$ ). Whether or not there is a liquidity trap in period $t+1$, we can solve for the wage in period $t$. If the cash-in-advance constraint binds at date $t+1$, then (from expression (9b)) $\frac{w_{t}}{k_{t}}=\frac{M_{t+1}}{\beta_{t+1}}$. If, instead, the cash-in-advance constraint does not bind at date $t+1$, then $i_{t+1}=0$ and (from expression (6)) $\frac{w_{t}}{k_{t}}=\frac{1}{\beta_{t+1}} \frac{w_{t+1}}{k_{t+1}}$. Now, consider expressions (2) and (3). Together, they imply a notional solution for the nominal interest rate in period $t$, 
$\widetilde{i_{t}}=\frac{w_{t}}{k_{t} M_{t}}-1$

If the solution for $\tilde{i}_{t}$ in (14) is negative, then the cash-in-advance constraint (2) is slack, with the real money stock greater than consumption expenditures. In this case, the interest rate is equal to zero, and the economy is in a liquidity trap, in that the current money supply is irrelevant. ${ }^{19}$ Whether or not the economy is in a liquidity trap, we may then solve for the remainder of the date- $t$ variables, and then proceed to a solution for date $t-1$. Finally, to begin the backward solution process, assume that, for some date in the distant future, we know that the economy has a positive interest rate.

The procedure outlined provides a solution for the entire path of the economy for given paths of the policy variables $M$ and $\tau$. In order to ensure that the government's intertemporal budget constraint is satisfied, we iterate, revising the value of $\tau$ (which is assumed to be constant over time) with each iteration to meet the budget constraint. Once the iteration process converges, the value of $\tau$ to which behavior responds is consistent with the government's budget constraint, given that behavior.

Having laid out this solution algorithm, we may now demonstrate the claim made above, that a level shift in the money stock at the initial date, with no subsequent change in money growth rates, will have no impact on the number of periods during which the liquidity trap applies. Consider first dates $t$ from period $T-1$ onward, where $T$, once again, is the first date such that $i_{T}>0$. For these dates, the current wage is proportional to the next period's money stock.

\footnotetext{
${ }^{19}$ At the borderline where $\tilde{i}$ is exactly equal to zero, the interest rate will equal zero and the cash-in-advance will hold as an equality. It will not bind, though, in the sense that the equilibrium would be unaffected by relaxing the constraint.
} 
Thus, with no change in the money growth rate between $t$ and $t+1$, the value of $\widetilde{i}_{t}$ yielded by expression (14) does not change. Now, consider any date $t$ before $T-1$. At this date, the wage is proportional to the wage at date $T-1$, and hence to the money stock at date $T$. From (14), there will be no impact of the value of $\widetilde{i_{t}}$ at $t$ if the growth of the money stock between periods $t$ and $T$ is unchanged.

It is useful to note that in this model the equilibrium is unique. Benhabib, Schmitt-Grohé, and Uribe (2002) demonstrate that the zero-bound on nominal interest rates can generate multiple equilibria when the monetary authority follows a Taylor-like rule to set the interest rate. Our model escapes this problem because it does not include a feedback policy rule for the nominal interest rate. ${ }^{20}$ It is easy to demonstrate, using the solution technique just described, that changing the terminal period has no impact on the equilibrium path. That is, suppose we first assume that the economy is permanently out of a liquidity trap as of date $\Psi$ and solve backward from that date. If the assumption is consistent with this solution, i.e., if the path after $\Psi$ exhibits positive interest rates, then starting the solution from any date $\Psi^{\prime}>\Psi$ will yield the same equilibrium path for the economy.

We now turn to some numerical simulations. As noted in the previous section, the theoretical model studied here has no government spending other than debt service. To remedy this omission in the simulations, we add a stream of government purchases to the government's intertemporal budget constraint. Purchases at each date $t$ are assumed to be exogenous and, like consumption at that date, proportional to the term $1 / k_{t}$ (see expression (3)). Thus, for a given

\footnotetext{
${ }^{20}$ Benhabib, Schmitt-Grohé, and Uribe (2002) also investigate conditions under which an anticipated switch from an interest-rate rule to monetary-base targeting can prevent deflationary equilibria from emerging. The model precludes self-fulfilling deflationary paths in which nominal interest rates are zero notwithstanding nonnegative money-supply growth. Consumers' desire eventually to spend their rapidly increasing real money balances makes such paths inconsistent with overall equilibrium.
} 
mark-up, interest rate and tax rate, government purchases will be a constant share of output and consumption over time. We adjust this share so that the tax rate in the initial equilibrium equals the estimate given above for government's share of output in Japan, 47 percent. As before, we also set the initial ratio of high-powered money to high-powered money plus debt at 0.2 . For each simulation, we consider the welfare effects of a change in monetary policy in terms of the equivalent variation in resources that would provide the same change in utility. ${ }^{21}$

Because we are interested in studying an economy that is initially in a liquidity trap, we make parameter assumptions consistent with this being the case. Following the assumptions of the previous section, we let the pure rate of time preference initially be negative (-0.03), having it become positive $(+0.02)$ in period 5. In terms of the discount factor itself, $\beta$ initially is $1 / 0.97$, falling to $\beta_{5}=\beta_{6}=\ldots=1 / 1.02$ in period 5 . The low initial rate of time preference pushes the nominal interest rate lower, making a liquidity trap more likely. We also assume that the labordisutility parameter, $k$, falls at an annual rate of .05 , reaching 1.0 in period 5 , when it ceases falling and remains constant thereafter. As discussed, variations in this parameter may be thought of in the same terms as variations in the rate of productivity, with falling $k$ being equivalent to increasing productivity. If productivity is relatively low now but is expected to be higher in the future, then inflation will be lower to make room for the real balances needed to support higher income levels. ${ }^{22}$ We set the competition parameter, $\rho$, equal to 10 , which induces

\footnotetext{
${ }^{21}$ Given the quasi-linear form of the utility function, hypothetical variations in income are absorbed by changes in labor supply, so the calculation amounts to finding the equivalent increase or decrease in labor supply necessary to give the same change in utility.

${ }^{22}$ In the context of present-day Japan, one cause of temporarily low productivity might be the banking system's distress, which makes it difficult for firms to finance productivity-enhancing investments. Hayashi and Prescott (2002) attribute Japan's recent output stagnation to low productivity growth, although they argue against the view that financial-system problems have hampered investment.
} 
a modest price-cost ratio of 10/9. Finally, in the initial equilibrium, we set the money stock to 1.0 in period 0 and assume that it grows at a constant annual rate of 2 percent thereafter.

Figure 2 shows the initial equilibrium trajectory of the money stock, inflation rate, and nominal interest rate for the economy just described. Despite a growing money stock, the economy is in a liquidity trap in periods 0 through 4 , with a zero nominal interest rate and prices falling at a rate just over 2 percent per year. The period 5 shift in preferences brings the economy out of the liquidity trap, with the interest rate rising to just over 4 percent and deflation ending. Actually, deflation lessens starting in period 4, due to firms' forward-looking pricing policies.

Figure 3 shows the impact of one-time increases in the money stock effected by openmarket operations in period 0 . Recall that in our model, this family of policies has no impact on the timing of the liquidity trap or the interest rate at any date. The figure shows the money stock and inflation trajectories under the baseline equilibrium already discussed, and alternative paths for period-0 increases in the money stock of 1 percent, 10 percent and 50 percent. The welfare gains from these policies are, respectively, 0.09 percent, 0.84 percent and 2.95 percent of output per year. The first of these annual gains is somewhat higher than the 0.05 percent derived for a comparable experiment in the previous section, a difference explained by the presence here of the additional distortions of price-cost mark-ups and (after period 4) positive nominal interest rates (see expression (12)). As predicted, the gains are not linear in money stock changes - the gain for a 50-percent increase in the money stock is about two-thirds of the value forecast by linear extrapolation of the gain for a 1-percent increase. Still, the gain is sizable-nearly 3 percent of output. Such a large jump in the money stock does cause inflation-here nearly 20 percent per year for two years - but the severity of this temporary surge in inflation is an artifact 
of our assumption that prices adjust over two periods. In this model, a longer period of price adjustment likely would yield a smaller spike and a more prolonged period of inflation within the liquidity trap regime.

Unlike a one-time, unannounced increase in the money stock, a change in the rate of growth of the money stock while the economy is in a liquidity trap has the potential to bring the economy out of a liquidity trap immediately. This is illustrated in Figure 4, which presents trajectories for the initial equilibrium and for an equilibrium in which the annual growth rate of the money stock is raised from 2 percent per year to 7 percent per year through period 5 . By the end of this transition period, the money stock is 33 percent higher than in the base case with 2 percent money growth.

With faster money growth, the liquidity trap ends immediately—-the interest rate in period 0 is close to its long-run value. Being out of the liquidity trap, the economy's inflation rate is dictated by this faster money growth rate, and exceeds that of the baseline equilibrium throughout the initial period. This inflation is still modest—ranging from less than 2 percent in year 5 to just below 8 percent in year 1 . The welfare gain is 0.92 percent of output per year. Though still significant, this is only slightly higher than the gain from an immediate increase in the money stock of 10 percent, and well below the yearly gain that an immediate 33-percent increase in the money stock would deliver -2.25 percent of output. The gradual increase in the money stock weakens the welfare gain by pushing interest rates up immediately, lessening the short-run output surge that accompanies an unexpected burst of inflation. ${ }^{23}$ This is illustrated in Figure 5, which shows consumption trajectories for the baseline equilibrium, the equilibrium

\footnotetext{
${ }^{23}$ Our cash-in-advance model's baseline version, which implies a unitary elasticity of consumption with respect to the nominal interest factor, probably exaggerates the welfare cost of deviations from Friedman's optimum quantity of money. The effect is proportionally lower, however, for lower values of the intertemporal substitution elasticity $\gamma$. As we have noted, of course, lowering $\gamma$ will lower other welfare effects as well.
} 
with faster money growth, and the equilibrium with an immediate jump in the money stock of the same size. Note that the temporary rise in consumption is much smaller under the policy of faster growth, and consumption actually then falls below the baseline trajectory temporarily due to the higher nominal interest rate.

To conclude this section, we emphasize some general lessons of these simulations. First, the inflationary effects of a step increase in money may well be front-loaded. Even a substantial increase in money could give way to moderate inflation, and possibly a temporary return to deflation, after a transition period. With different parameter settings implying a strong enough underlying deflationary trend, a policy of monetary injections might also succeed only in reducing, but not eliminating, deflation. Nonetheless, substantial welfare gains can be reaped. These observations are relevant in assessing the credibility of permanent monetary expansion, the topic of the next section.

\section{Credibility of Permanent Money Supply Changes}

As we have noted, Krugman's (1998) dynamic model of the liquidity trap relies on a belief among market actors that the central bank has a rigid future target for the money-supply level. Under that assumption, any announced future increase in the money supply's level lacks credibility and markets expect any current increase to be fully reversed later on. Of course, were Krugman's assumption literally true in our model, the central bank would lose its ability to influence the economy today through open-market operations. Our model and simulations, suggest, however, that the preceding characterization of an inflation-averse central bank is unrealistically extreme.

In our simulations, a central bank that is acting against a deflationary trend can achieve a substantial welfare gain while creating only mild and temporary inflation. It is hard to see why 
this outcome would not be preferred to ongoing deflation even by very hawkish central bankers. Furthermore, there is no welfare gain to reversing a permanent money-stock increase (or, equivalently in our setup, to reneging on a promise to raise the date $T$ money stock). On the contrary, such a move would have a negative welfare impact in our model compared to nonreversal. This finding is consistent with Eggertsson's (2003) observation that when national policymakers internalize the fiscal benefits of monetary expansion, permanent money-stock increases can become quite credible. Our detailed numerical results suggest, moreover, that for Japan the fiscal benefits are large enough to overwhelm any reasonable fears about inflation, especially starting from a position where prices actually are falling. In other words, the government's net debt is already so large that it should perceive very powerful fiscal incentives to end deflation.

Eggertsson (2003) argues, however, that an independent central banker's preferences might diverge from those of the government. In the extreme, the banker might have a lexicographic abhorrence of inflation, and thus be entirely blind to the associated benefits from public debt reduction and lower taxes. We doubt this is the case anywhere. Independent central bankers routinely warn of the dangers of high tax levels and of high public deficits and debts. In the specific case of Japan, the revised Bank of Japan Law that became effective in 1998 indeed grants the central bank goal- as well as instrument-independence. Yet the Bank's assigned mission of pursuing "price stability, contributing to the sound development of the national economy," is not at all inconsistent with the simulated policy effects of the last section. ${ }^{24}$ If Japan's central bankers care even to a limited degree about the negative effects of tax distortions, a policy of at least some permanent monetary expansion should be attractive to them, once they

\footnotetext{
${ }^{24}$ Furthermore, Article 4 of the recent Bank of Japan Law states that the Bank shall "always keep close contact with the government and exchange views sufficiently so that its currency and monetary control and the basic stance of the government's economic policy shall be mutually harmonious." See Cargill, Hutchison, and Ito (2000, pp. 97-101).
} 
understand the magnitude of the fiscal benefits available. Furthermore, the likely front-loading of inflationary effects makes a later policy reversal unlikely unless the Bank of Japan is targeting a definite historical price level, in the mode of an interwar central bank returning to a pre-1914 gold exchange parity. This behavioral model is, fortunately, no longer plausible.

A reflationary strategy focused on pegging the exchange rate, such as the one advocated by Svensson (2001), is in purely economic terms quite similar in its fiscal implications. In principle such a policy could be decided by the government without decisive central bank input, but the approach suffers from credibility problems of its own. A substantial and purposeful exchange rate devaluation by the government of Japan would elicit strong protests from trading partners, and hence pressures for reversal. From a political point of view, the incremental market-induced depreciations following gradual money-supply expansion would be easier to defend as a side product of domestically necessary policies. ${ }^{25}$ Furthermore, if the Japanese government is indeed viewed as committed to a low long-run price-level target, the yen currency peg could be susceptible to a revaluation attack, as were the German and Swiss currencies near the end of the Bretton Woods period.

The Bank of Japan has already expanded the monetary base from a 1999 annual average of $¥ 63.5$ trillion to a 2002 annual average of $¥ 90$ trillion, an increase of 42 percent, with no discernible inflationary impact. Is the seeming failure to ignite inflation evidence of deflationary expectations so entrenched that open-market policy cannot be effective? Not necessarily. Japan's price level could well have fallen even more absent the monetary ease. Our findings

\footnotetext{
${ }^{25}$ A large immediate money-stock increase, in contrast, would have the advantage of signaling a dramatic break with the past, and to the extent that its inflationary effects were front-loaded, any temptations to reversal would be reduced. While the exchange-rate effects would be more obvious to trading partners, the Japanese government could still claim in its defense that the depreciation was a side effect of other necessary policies.
} 
suggest that the Bank of Japan's quantitative operations have had a positive welfare effect, and would help the economy further if fully maintained and carried out even more aggressively.

The experience of the United States during the Great Depression provides a useful perspective on Japan's effort at monetary stimulus. Figure 6 shows that in the late 1930s, United States interest rates looked very much like those in Japan today, roughly zero at the short end but significantly positive at long maturities. Dollar devaluation in April 1933, followed by growing political instability in Europe, inspired accelerating capital inflows to the United States that increased the country's stock of monetary gold fivefold between 1933 and 1940. Over the same period the stock of high-powered money nearly tripled. ${ }^{26}$ Romer (1992) argues persuasively that this monetary expansion was the main cause of U.S. recovery from the Depression, especially the sharp 1938-1942 increase in output (by 49 percent). It is noteworthy that after a spike in inflation due to the 1933 devaluation, the U.S. price level rose only gradually until 1941. As is likely in Japan today, monetary expansion had to offset the deflationary pressure caused by an output level well below full employment. ${ }^{27}$ But monetary expansion did eventually work.

If the experience of the Great Depression is any guide, Japan will need more quantitative easing to escape from its liquidity trap, perhaps much more. The simultaneous opportunity for public debt reduction provides strong additional motivation for this policy.

\section{Summary and Conclusion}

We have confirmed the intuition that a substantial monetary expansion undertaken in a liquidity trap should improve welfare by reducing the taxes required in the future to service the national

\footnotetext{
${ }^{26}$ High-powered money data are taken from Friedman and Schwartz (1963). All other data cited are from the NBER Macro History database.

${ }^{27}$ Romer (1999) discusses U.S. price dynamics in this period and finds an important role for nonmonetary factors.
} 
debt. This, in itself, is an important finding, for it suggests a role for monetary policy even if the policy has no immediate impact on prices, output or interest rates.

But we have also shown that this policy can effect an immediate expansion in prices and, with less than fully flexible prices, output as well. Thus, monetary policy remains an important policy instrument for an economy mired in a liquidity trap, even if the liquidity trap is severe and expected to last a long time. Given the surprising clarity of these results, and the fact that they are inconsistent with much "conventional wisdom," it is worth asking the extent to which there may be important institutional factors missing from our analysis that might substantially weaken or overturn them.

One simplification of our model has been the omission of financial intermediaries. At first, this might appear to be a critical and questionable simplification. In reality, an expansion of the money stock requires not only an expansion of the monetary base by the monetary authority, but also a willingness of banks to lend the additional reserves that the central bank has made available. Given the weakness of Japan's banking sector, might this represent a roadblock to successful implementation of the policy traced out above? In short, the answer is no, following logic similar to that used above.

As discussed, a monetary expansion undertaken in a liquidity trap "works" through its effect on the money stock after the liquidity trap regime elapses, at date $T$ in our notation. This expansion can be accomplished through an immediate increase in the money stock at date 0 that is sustained through date $T$, but the actual date of the initial expansion before date $T$ is irrelevant. If the government waited until date $T$ to increase the money stock, for example, the effects at date 0 would be unaffected, as long as the money stock at date $T$ were the same. Following this logic, we can see that it is unnecessary for banks to respond immediately to an open-market 
increase in reserves by the central bank. Perhaps they might choose initially to hoard the reserves in the face of zero short-term interest rates. But, when the liquidity trap regime gives way to one with positive short-term interest rates—at date $T$ — banks would be expected to lend their reserves to profit from the interest differential between reserves and loans. Thus, the presence of banks might affect the timing of the eventual monetary expansion, conditional on the central bank's operations, but it should not nullify the policy's efficacy. Of course, to the extent that expansionary monetary policies aid troubled banks in writing off bad loans and returning to active lending, the case for central bank bond purchases is strengthened further.

Entrenched price expectations surely are a barrier to policy success in Japan. In view of the large economic benefits available, however, sustained policy action coupled with better communication of strategy to the public should be able to modify the deflationary psychology. 


\section{Appendix on the Government Budget Constraint}

Consider the government's budget constraint. Starting with the expression above for the evolution of household wealth,

$V_{t+1}=V_{t}\left(1+r_{t}\right)+\frac{\pi_{t}}{P_{t}}+\frac{w_{t} L_{t}}{P_{t}}-\left(1+\tau_{t}\right)\left(1+i_{t}\right) C_{t}$,

we impose the national income identity equating purchases to factor incomes and obtain:

$V_{t+1}=V_{t}\left(1+r_{t}\right)-\left[\left(1+\tau_{t}\right)\left(1+i_{t}\right)-1\right] C_{t}$.

Imposing the transversality condition, we get:

$$
\begin{aligned}
V_{0} & =\sum_{t=0}^{\infty}\left(\prod_{s=0}^{t}\left(1+r_{s}\right)^{-1}\right)\left[\left(1+\tau_{t}\right)\left(1+i_{t}\right)-1\right] C_{t} \\
& =\sum_{t=0}^{\infty}\left(\prod_{s=0}^{t}\left(1+i_{s}\right)^{-1}\right) \frac{P_{t}}{P_{-1}}\left[\left(1+\tau_{t}\right)\left(1+i_{t}\right)-1\right] C_{t} \\
& =\frac{1}{P_{-1}} \sum_{t=0}^{\infty}\left(\prod_{s=0}^{t}\left(1+i_{s}\right)^{-1}\right)\left[\left(1+\tau_{t}\right)\left(1+i_{t}\right)-1\right] \frac{w_{t}}{k_{t}\left(1+i_{t}\right)\left(1+\tau_{t}\right)} \\
& =\frac{1}{P_{-1}} \sum_{t=0}^{\infty}\left(\prod_{s=0}^{t}\left(1+i_{s}\right)^{-1}\right)\left[1-\frac{1}{\left(1+i_{t}\right)\left(1+\tau_{t}\right)}\right] \frac{w_{t}}{k_{t}} \\
\Rightarrow & \left(M_{0}+B_{0}\right)=\sum_{t=0}^{\infty}\left(\prod_{s=0}^{t}\left(1+i_{s}\right)^{-1}\right)\left[1-\frac{1}{\left(1+i_{t}\right)\left(1+\tau_{t}\right)}\right] \frac{w_{t}}{k_{t}} .
\end{aligned}
$$

This expression relates the government's current obligations to its future seigniorage and tax revenue. Note that an open market operation has no impact on the left-hand side of the 
expression, so one solves for the change in tax rates that keeps the right-hand side constant as the policy changes.

Finally, let us assume that the tax rate $\tau$ is constant over all future periods. With this assumption, the path of wages obtained in the text of the paper, and the fact that the interest rate is 0 through date $T-1$ and determined by the Euler equation based on successive money stocks from $T$ onward, we may use the above expression for the government's budget constraint to solve for the necessary tax rate, $\tau$. We solve for $\tau$ to obtain

$$
\tau=\frac{\frac{M_{0}+B_{0}}{\left(\prod_{t=0}^{T} \beta_{t}^{-1}\right) M_{T}}-\sum_{t=T}^{\infty}\left(\prod_{s=0}^{t} \beta_{s}\right)\left(1-\beta_{t+1} \frac{M_{t}}{M_{t+1}}\right)}{\sum_{t=0}^{\infty}\left(\prod_{s=0}^{t} \beta_{s}\right)-\frac{M_{0}+B_{0}}{\left(\prod_{t=0}^{T} \beta_{t}^{-1}\right) M_{T}}} .
$$

The second term in the numerator reflects the seigniorage collected on household holdings of money after date $T$-1. The term $\left(\prod_{t=0}^{T} \beta_{t}^{-1}\right) M_{T}$ measures the impact of the money stock at date $T$ on the wage rate at date 0 . Under the assumption that the cash-in-advance constraint only starts to bind for cash balances held at the beginning of date $T$, the money stock before $T$ is irrelevant to the determination of wages and prices. 


\section{References}

Akerlof, George A., William T. Dickens, and George L. Perry. "The Macroeconomics of Low Inflation." Brookings Papers on Economic Activity (1:1996): 1-76.

Barro, Robert J., and David B. Gordon. "A Positive Theory of Monetary Policy in a Natural Rate Model.” Journal of Political Economy 91 (August 1983): 589-610.

Benhabib, Jess, Stephanie Schmitt-Grohé, and Martin Uribe. “Avoiding Liquidity Traps.” Journal of Political Economy 110 (June 2002): 535-63.

Bernanke, Ben S. “Japanese Monetary Policy: A Case of Self-Induced Paralysis?” In Japan's Financial Crisis and Its Parallels to U.S. Experience, ed. Adam S. Posen and Ryoichi Mikitani. Washington, D.C.: Institute for International Economics, 2000.

Calvo, Guillermo A. "On the Time Consistency of Optimal Policy in a Monetary Economy." Econometrica 46 (November 1978): 1411-28.

Cargill, Thomas F., Michael M. Hutchison, and Takatoshi Ito. Financial Policy and Central Banking in Japan (Cambridge, MA: MIT Press, 2000).

Dekle, Robert. “The Deteriorating Fiscal Situation and an Aging Population.” Working Paper no. 9367, National Bureau of Economic Research (December 2002).

Eggertsson, Gauti. "How to Fight Deflation in a Liquidity Trap: Committing to Being Irresponsible.” Photocopy: International Monetary Fund (February 2003).

Eggertsson, Gauti, and Michael Woodford. "The Zero Bound on Interest Rates and Optimal Monetary Policy." Brookings Papers on Economic Activity (1:2003): forthcoming.

Friedman, Milton, and Anna Jacobson Schwartz. A Monetary History of the United States, $1867-$ 1960 (Princeton, NJ: Princeton University Press for the National Bureau of Economic Research, 1963). 
Goyal, Rishi, and Ronald McKinnon. “Japan's Negative Risk Premium in Interest Rates: The Liquidity Trap and Fall in Bank Lending.” World Economy 26 (March 2003): 339-63. Hayashi, Fumio, and Edward C. Prescott. “The 1990s in Japan: A Lost Decade.” Review of Economic Dynamics 5 (January 2002): 206-35.

Kashyap, Anil K. “Sorting Out Japan’s Financial Crisis.” Working Paper no. 9384, National Bureau of Economic Research (December 2002).

King, Mervyn. "Challenges for Monetary Policy: New and Old.” In New Challenges for Monetary Policy (Kansas City, MO: Federal Reserve Bank of Kansas City, 1999).

Krugman, Paul R. 'It's Baaack: Japan's Slump and the Return of the Liquidity Trap.” Brookings Papers on Economic Activity (2:1998): 137-205.

Ministry of Finance, Japan. Current Japanese Fiscal Conditions and Issues to Be Considered. http://www.mof.go.jp/english/budget/pamphlet/cjfc.htm (July 2002).

Romer, Christina D. "What Ended the Great Depression?” Journal of Economic History 52 (December 1992): 757-84.

Romer, Christina D. "Why Did Prices Rise in the 1930s?” Journal of Economic History 59 (March 1999): 167-99.

Schmitt-Grohé, Stephanie, and Martin Uribe. “Optimal Fiscal and Monetary Policy under Sticky Prices.” Working Paper no. 9220, National Bureau of Economic Research (September 2002).

Shirakawa, Masaaki. “One Year under 'Quantitative Easing’.” Discussion Paper no. 2002-E-3, Institute of Monetary and Economic Studies, Bank of Japan (April).

Svensson, Lars E. O. “The Zero Bound in an Open Economy: A Foolproof Way of Escaping from a Liquidity Trap.” Monetary and Economic Studies 19 (February 2001): 277-312. 
Wolman, Alexander L. "A Primer on Optimal Monetary Policy with Staggered Price Setting." Federal Reserve Bank of Richmond Economic Quarterly 87 (Fall 2001): 27-52.

Woodford, Michael. Interest Rates and Prices: Foundations of a Theory of Monetary Policy (Princeton, NJ: Princeton University Press, 2003). 

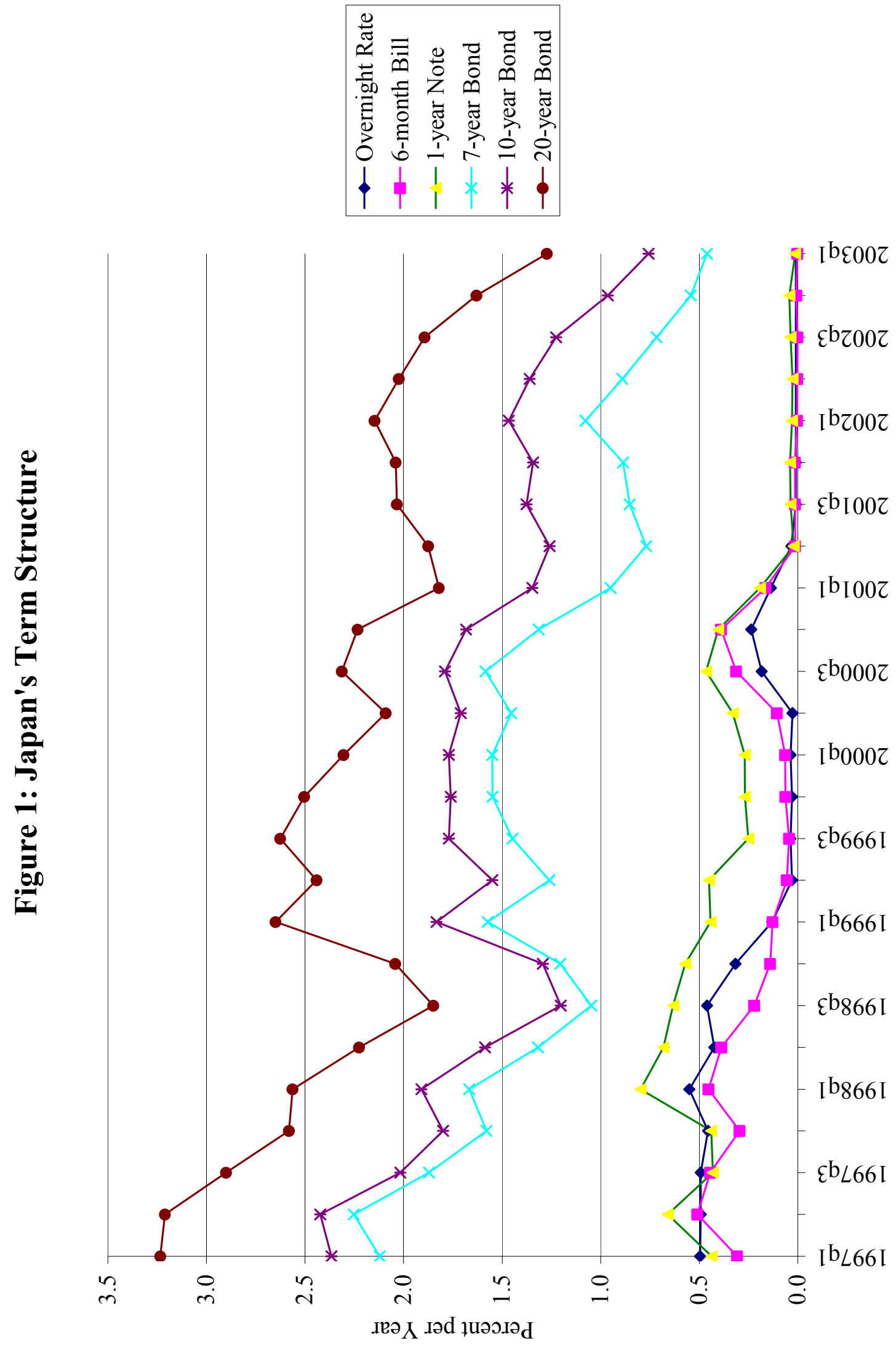

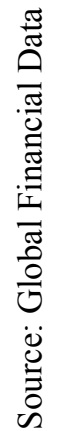




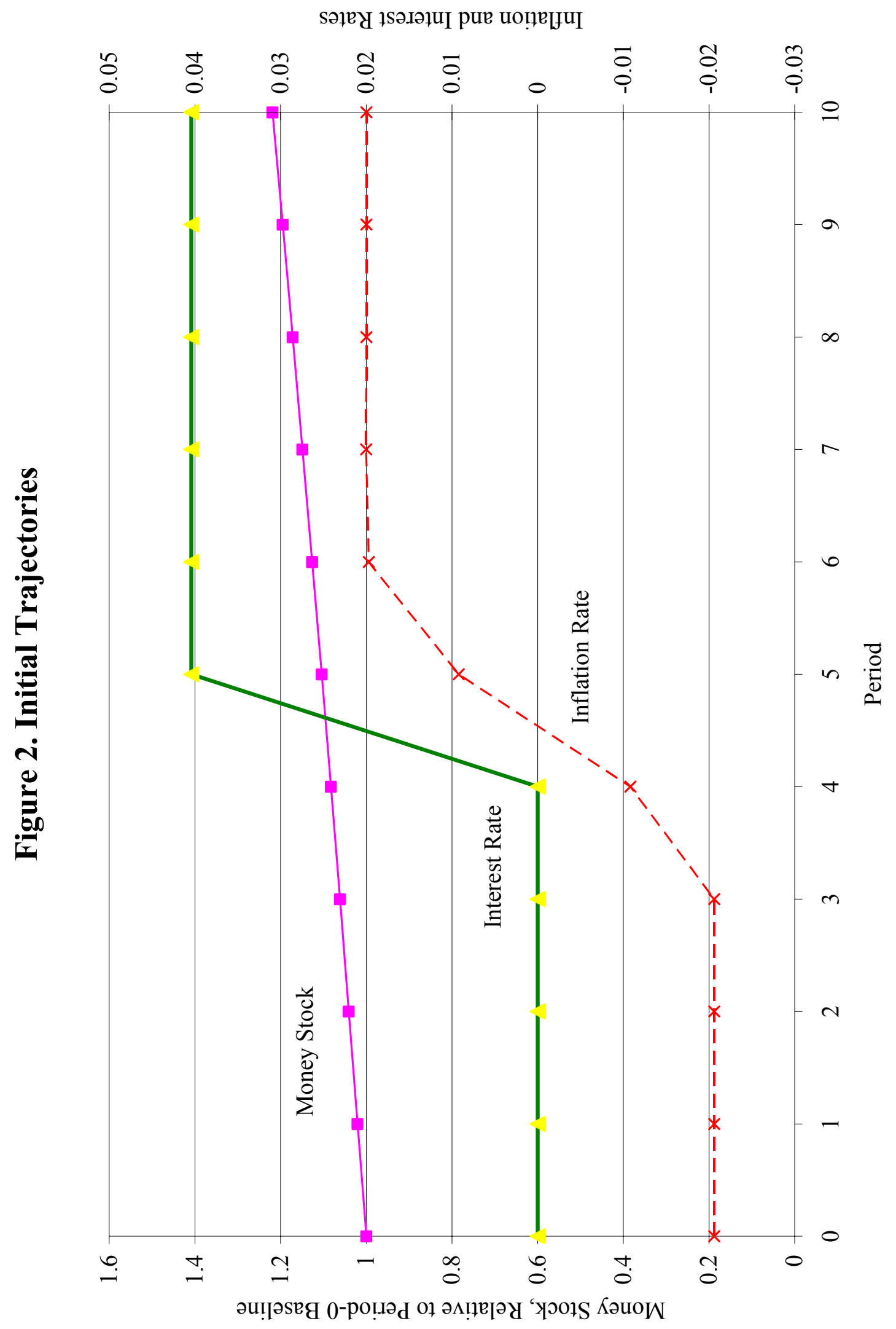




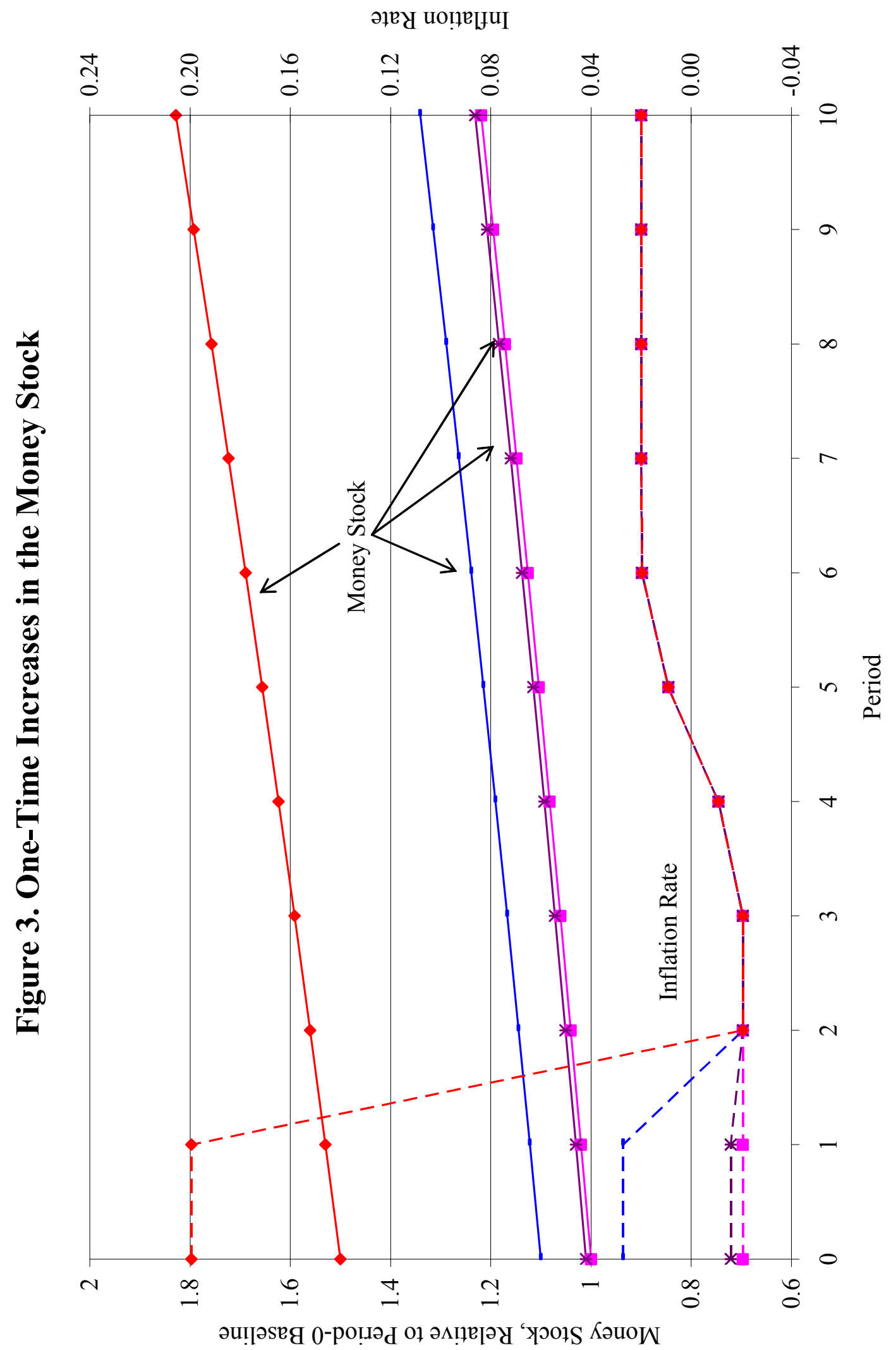




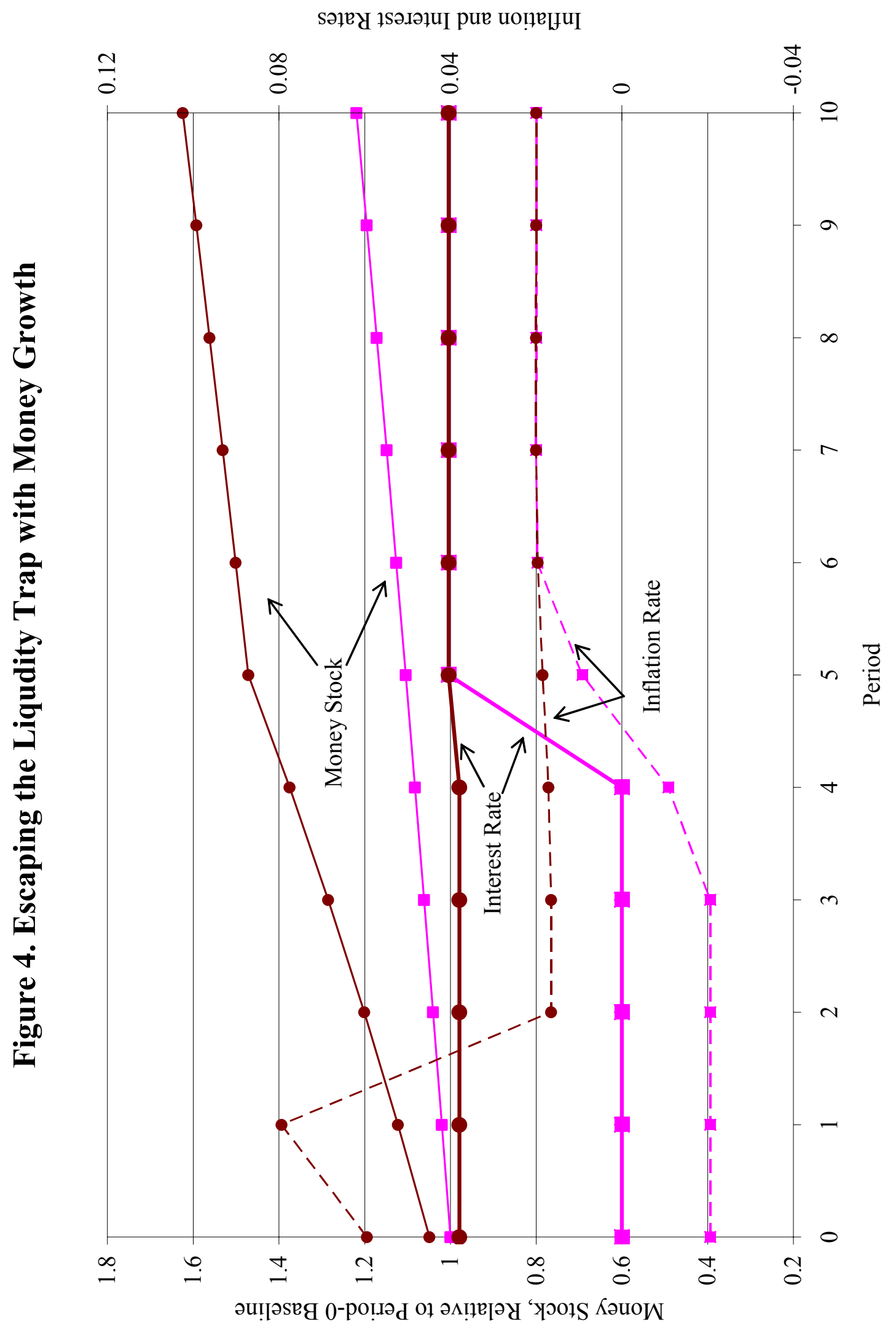




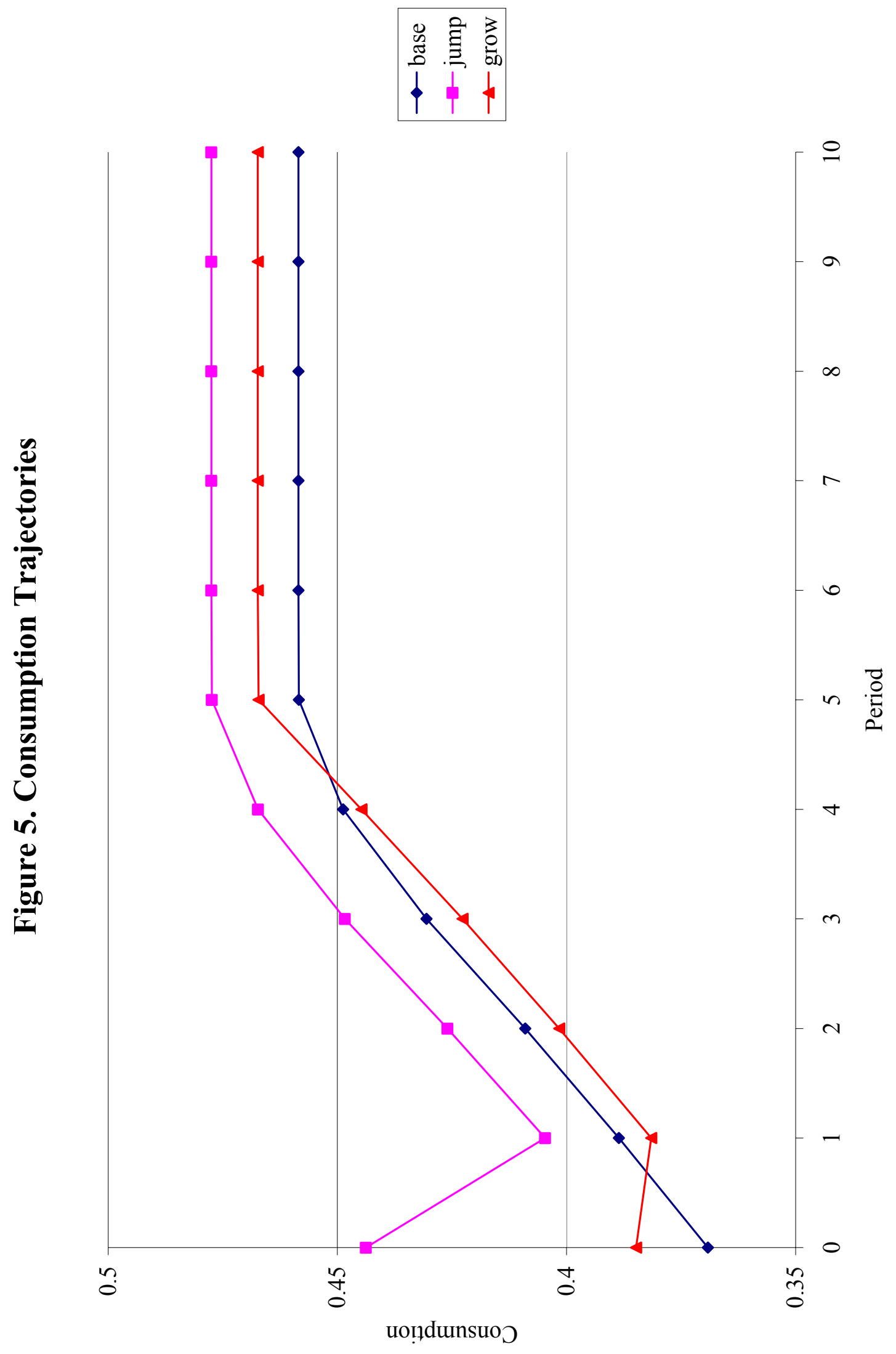




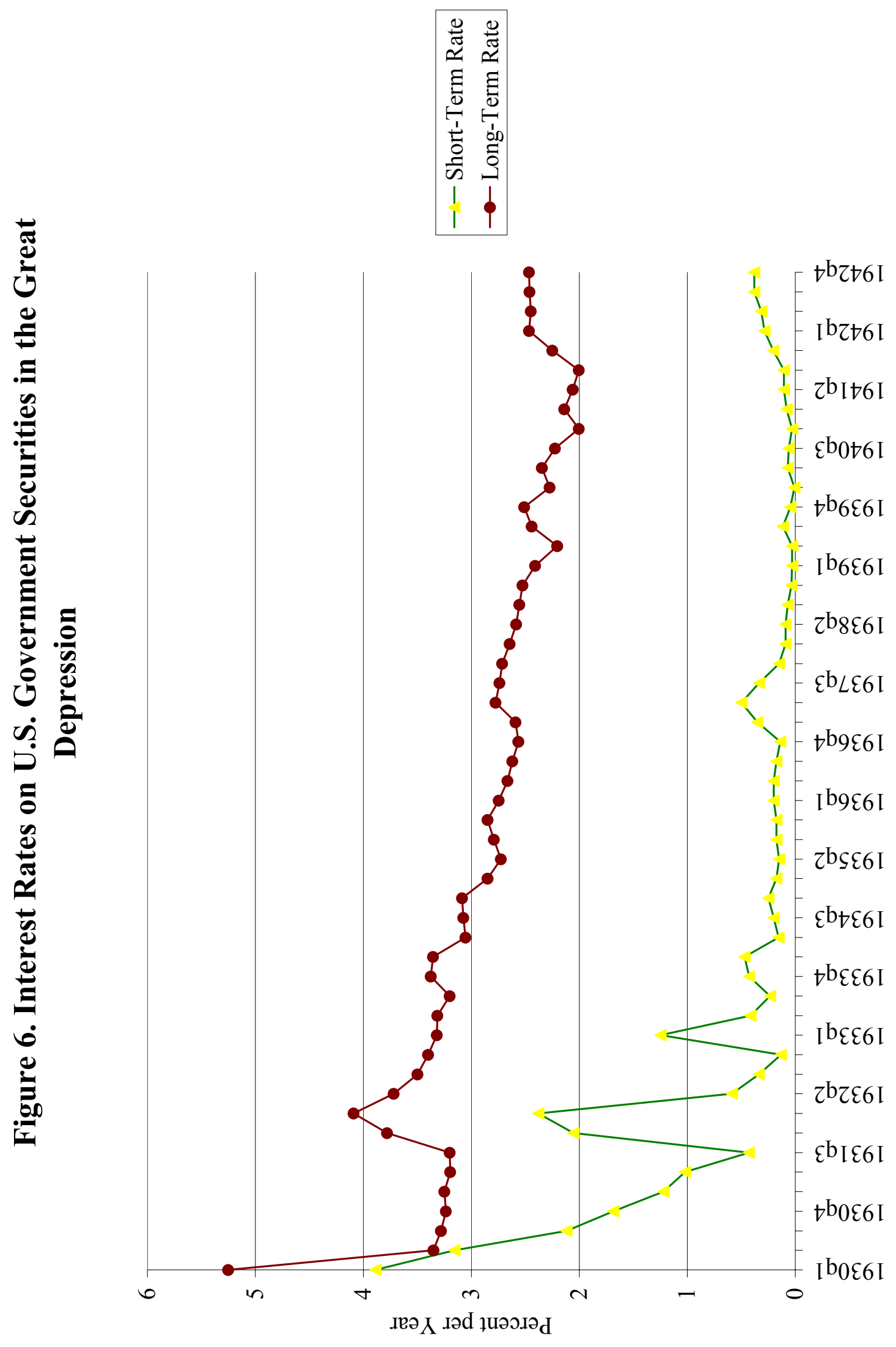

